\title{
PENGARUH KOMPETENSI DAN BUDAYA KERJA TERHADAP KINERJA KARYAWAN
}

\author{
P.A. Irmayanti ${ }^{1}$, N.M.A. Widiastini ${ }^{2}$, I.N. Suarmanayasa ${ }^{3}$ \\ 1,2,3 Jurusan Manajemen, Universitas Pendidikan Ganesha, Singaraja. \\ e-mail: irmayantiagnes@gmail.com, ary.widiastini@undiksha.ac.id, nengah.suarmanayasa@undiksha.ac.id
}

\begin{abstract}
Abstrak
Penelitian ini bertujuan untuk menguji pengaruh kompetensi terhadap kinerja karyawan, budaya kerja terhadap kinerja karyawan serta kompetensi dan budaya kerja terhadap kinerja karyawan. Desain penelitian yang digunakan adalah penelitian kuantitatif kausal. Subjek penelitian ini adalah karyawan Divisi Umum dan SDM Rumah Sakit Umum Karya Dharma Husada Bros Singaraja dan objek penelitian ini adalah kompetensi, budaya kerja, dan kinerja karyawan. Populasi dalam penelitian ini berjumlah 50 orang. Data dikumpulkan dengan kuesioner, wawancara, dan observasi. Analisis data yang digunakan adalah analisis regresi linear berganda. Hasil penelitian ini menunjukkan bahwa kompetensi berpengaruh secara positif dan signifikan terhadap kinerja karyawan, budaya kerja berpengaruh secara positif dan signifikan terhadap kinerja karyawan serta kompetensi dan budaya kerja berpengaruh secara positif dan signifikan terhadap kinerja karyawan
\end{abstract}

Kata kunci: kompetensi, budaya kerja, kinerja karyawan

\begin{abstract}
The purpose of this research is to test the impact of (1) competence on employee performance, work culture on employee performance, competence and work culture on employee performance. The research design used is causal quantitative research. The subject of this study is all employees of the divisi umum dan SDM Rumah Sakit Umum Karya Dharma Husada Bros Singaraja the object of this study is competence, work culture and employee performance. The population of this studi is 50. Data collected by questionnaires, interviews, and observation. The data analysis used is multiple linier regression analysis. The results of this study indicate that the competence has a positive and significant impact on the performance employee work culture has a positive and significant impact on the performance employee and the competence and work culture has a positive significant on the performance employee
\end{abstract}

Keyword: employee performance, competence, work culture.

\section{PENDAHULUAN}

Konsep manajemen sumber daya manusia merupakan salah satu aspek yang terpenting dalam berjalannya suatu perusahaan maupun organisasi untuk mencapai visi, misi maupun tercapainya tujuan perusahaan maupun organisasi. Agar aktivitas perusahaan dapat berjalan secara baik, lancar dan berkesinambungan, maka sangat diperlukan karyawan yang dapat bekerja cekatan dengan tingkat kesetiaan yang tinggi untuk perusahaan di tempat kerja. Sumber daya manusia merupakan suatu aset penting bagi perusahaan maupun organisasi karena perannya sebagai subjek pelaksana kebijakan dan kegiatan operasional perusahaan. Salah satu sumber daya yang dimiliki oleh suatu perusahaan seperti modal, metode, material dan mesin tidak akan bisa memberikan hasil yang optimum apabila tidak di dukung oleh sumber daya manusia yang berkompeten di bidangnya yang mempunyai kinerja yang optimum pula (Mangkunegara, 2005). Sudah dapat dipastikan bahwa sumber daya manusia merupakan salah satu sumber daya yang paling bisa menentukan sukses tidaknya suatu perusahaan maupun organisasi. Kualitas dan kuantitas kerja karyawan merupakan unsur yang sangat penting dalam meningkatkan prestasi, kinerja dan tingkat kemajuan suatu perusahaan.

Era globalisasi dengan perkembangan ilmu pengetahuan, teknologi, informasi yang berkembang dan tingkat persaingan yang sangat tinggi segala aspek perusahaan jasa, segala suatu hal dituntut untuk memberikan kontribusi melalui kinerjanya secara optimal dan juga memuaskan hal tersebut guna mengetahui seberapa besar seorang karyawan dapat 
memberikan segala kemampuan beserta kontribusi bagi perusahaan tempatnya bekerja dan seberapa optimal kinerja dari seorang karyawan tersebut. Menurut Hasibuan (2006) kinerja adalah suatu hasil kerja yang dicapai seseorang dalam melakukan tugas-tugas yang dibebankan kepadanya didasarkan atas kecakapan, pengalaman, dan kesungguhan serta waktu. Salah satu institusi yang juga dituntut untuk memberikan pelayanan yang optimal dan juga dituntut dalam hal peningkatan kinerja seluruh karyawannya salah satunya adalah rumah sakit.

Menurut WHO (World Health Organization) (2008) Rumah Sakit merupakan bagian integral dari suatu organisasi sosial dan kesehatan dengan fungsi menyediakan pelayanan paripurna (komprehensif), penyembuhan penyakit (kuratif), pencegahan penyakit (preventif) kepada masyarakat. Rumah sakit juga merupakan pusat pelatihan tenaga kesehatan dan pusat penelitian medik. Perusahaan yang bergerak di bidang pelayanan jasa sebuah institusi dan perawatan kesehatan profesional yang pelayanannya disediakan oleh dokter, perawat dan tenaga ahli kesehatan lainnya. sebagai salah satu sub sistem pelayanan kesehatan yang menyelenggarakan dua jenis pelayanan, yaitu pelayanan kesehatan dan pelayanan administrasi. Pelayanan kesehatan meliputi pelayanan medik, penunjang medik, rehabilitasi medik, dan layanan keperawatan. Pelayanan administrasi yang mencakup semua jenis pelayanan yang bersifat administratif yang terdiri dari beberapa divisi seperti keuangan, humas, keperawatan, dan divisi umum dan sumber daya manusia. Subjek dari penelitian ini adalah seluruh karyawan Divisi Umum dan Sumber Daya Manusia yang ada di Rumah Sakit Umum Karya Dharma Husada Bros Singaraja yang berjumlah 50 orang. Yang terdiri dari karyawan perempuan yang berjumlah 33 orang, dan karyawan laki-laki yang berjumlah 17 orang.

Divisi Umum dan Sumber Daya Manusia adalah bagian dari divisi administrasi dan umum dari rumah sakit yang mempunyai tugas melaksanakan kegiatan pengelolaan pegawai, pengembangan pegawai, dan kesejahteraan pegawai, yang langsung memonitor berbagai informasi penting yang terkait dengan kesejahteraan pegawai seperti kenaikan pangkat, pengelolaan gaji, insentif, tunjangan dan lain-lain. Adapun beberapa tugas divisi umum dan sumber daya manusia yaitu menyusun program kerja dan rencana sumber daya dan kepegawaian agar tugas-tugas dapat dilaksanakan dengan lancar, menyusun pengembangan sumber daya manusia, melayani dan mempersiapkan surat menyurat dan kegiatan lain yang berkaitan dengan ketatausahaan rumah sakit, mengadakan koordinasi dengan bagian lain dalam rangka pembinaan pegawai, pengembangan karier maupun peningkatan kesejahteraan pegawai, membuat atau menyusun laporan berkala baik bulanan, triwulan maupun tahunan mengenai hasil kegiatan ataupun pekerjaan yang telah dilaksanakan, dan menjabarkan dan memberitahukan tentang kebijaksanaan pimpinan rumah sakit kepada bawahan untuk acuan tugas. Kinerja dapat diketahui dan diukur jika individu atau kelompok karyawan telah mempunyai kriteria standar keberhasilan tolak ukur yang ditetapkan oleh suatu perusahaan.

Hasibuan (2006) menyatakan kinerja adalah suatu hasil kerja yang dicapai seseorang dalam melakukan tugas-tugas yang dibebankan kepadanya didasarkan atas kecakapan, pengalaman, dan kesungguhan serta waktu. Berdasarkan hasil wawancara bersama Human Resources Department (HRD) Rumah Sakit Umum Karya Dharma Husada Bros Singaraja, terdapat beberapa masalah seperti pada divisi tersebut standar pendidikan minimum yang ditetapkan adalah $\mathrm{S} 1$, tetapi ada karyawan yang masih pendidikan terakhirnya SMA/SMK. Sehingga hal tersebut mengakibatkan kurangnya keterampilan karyawan dalam memenuhi segala tuntutan kerja, hal tersebut dapat mempengaruhi kinerja dari karyawan. Hal ini dapat terlihat dari pegawai yang seringkali masih ditemukan menunda pekerjaanya yang seharusnya pekerjaan dikerjakan di tempat kerja, tetapi pekerjaan tersebut tidak selesai tepat pada waktunya sehingga pekerjaan tersebut dikerjakan di rumah. Iswahyu (2014) kompetensi merupakan kemampuan pelaksanaan tugas sesuai dengan ilmu pengetahuan dan keterampilan serta teknologi dan pengalaman yang relevan dengan bidang tugas sehingga dapat mengembangkan motivasi kerja yang bersangkutan 
dan peningkatan kinerjanya. Kompetensi adalah perpaduan keterampilan, pengetahuan, kreativitas dan sikap positif terhadap pekerjaan tertentu yang diwujudkan dalam kinerja.

Sedangkan budaya kerja merupakan cara hidup perusahaan maupun organisasi yang diteruskan dari generasi yang satu kepada generasi lainnya kepada pekerja. Budaya sendiri merupakan pemahaman tentang siapa kita, apa yang kita kerjakan, apa yang kita yakini dan yang ada dalam suatu perusahaan tersebut, apa yang kita lakukan dan bagaimana cara dalam mengimplementasikan diri di dalam pekerjaannya. Menurut Mangkunegara (2005) yang dikutip dari Edgar H. Schein mendefinisikan bahwa budaya kerja adalah seperangkat asumsi atau sistem keyakinan, nilai-nilai dan norma yang dikembangkan dalam organisasi yang dijadikan pedoman tingkah laku bagi anggota-anggotanya untuk mengatasi masalah adaptasi eksternal dan integrasi internal Pada divisi umum dan SDM Ditemukan adanya permasalahan seperti Implementasi dari visi, misi maupun motto rumah sakit belum sepenuhnya tercapai oleh beberapa karyawan. Salah satu contohnya apabila terjadi pengecekan mendadak oleh tim sidak dari rumah sakit pusat, karyawan belum mampu menjelaskan dan belum memahami benar mengenai visi, misi tersebut.

Rendahnya kinerja karyawan sangat ditentukan oleh kompetensi dan juga budaya kerja di tempat bekerja. Hal ini sangat selaras dengan teori yang disampaikan oleh Wibowo (2007) mengatakan bahwa kompetensi dan budaya kerja dapat mempengaruhi kinerja karyawan. Kompetensi menjadi sangat berguna untuk membantu organisasi menciptakan budaya kinerja tinggi, prestasi kerja dan peningakatan kinerja karyawan. Kompetensi sangat penting karena merupakan karakteristik utama dan paling mendasar dari individu untuk menghasilkan suatu kinerja yang optimal dalam budaya kerja suatu perusahaan ataupun organisasi. Berdasarkan pemaparan latar belakang permasalahan diatas maka rumusan masalah yang dapat diambil yaitu (1) Bagaimana pengaruh kompetensi terhadap kinerja karyawan pada Rumah Sakit Umum Karya Dharma Husada Bros Singaraja?, (2) Bagaimana pengaruh budaya kerja terhadap kinerja karyawan pada Rumah Sakit Umum Karya Dharma Husada Bros Singaraja?, (3) Bagaimana pengaruh kompetensi dan budaya kerja terhadap kinerja karyawan pada Rumah Sakit Umum Karya Dharma Husada Bros Singaraja. Adapun tujuan dari penelitian ini yaitu (1) Pengaruh kompetensi terhadap kinerja karyawan pada Rumah Sakit Umum Karya Dharma Husada Bros Singaraja, (2) Pengaruh budaya kerja terhadap kinerja karyawan pada Rumah Sakit Umum Karya Dharma Husada Bros Singaraja (3) Pengaruh kompetensi dan budaya kerja terhadap kinerja karyawan pada Rumah Sakit Umum Karya Dharma Husada Bros Singaraja

Dari uraian latar belakang tersebut, bahwa fenomena yang terjadi pada kinerja karyawan divisi umum dan SDM dipengaruhi oleh kompetensi dan budaya kerja karyawan yang belum optimal. Maka dari itu dipandang perlu untuk melakukan penelitian yang berjudul "Pengaruh Kompetensi dan Budaya Kerja Terhadap Kinerja Karyawan Divisi Umum dan SDM Rumah Sakit Umum Karya Dharma Husada Bros Singaraja".

\section{KAJIAN PUSTAKA DAN PERUMUSAN HIPOTESIS}

Menurut Wibowo (2013) mengatakan bahwa setiap organisasi dibentuk untuk mencapai tujuan tertentu dan apabila tercapai barulah dapat disebut sebagai sebuah keberhasilan. Untuk mencapai keberhasilan, diperlukan landasan yang kuat berupa kompetensi kepemimpinan, kompetensi pekerja dan disiplin kerja yang mampu memperkuat dan memaksimumkan kompetensi. Kompetensi menjadi sangat berguna untuk membantu organisasi menciptakan budaya kinerja tinggi, prestasi kerja dalam setiap proses sumber daya manusia, seleksi karyawan, manajemen kinerja, perencanaan dan sebagainya. Menurut Iswahyu (2014) kompetensi merupakan kemampuan pelaksanaan tugas sesuai dengan ilmu pengetahuan dan keterampilan serta teknologi dan pengalaman yang relevan dengan bidang tugas sehingga dapat mengembangkan motivasi kerja yang bersangkutan dan peningkatan kinerjanya. Menurut Dessler (2006) mendefinisikan kompetensi sebagai karakteristik dari seseorang yang dapat diperhatikan yang meliputi pengetahuan, keterampilan, dan perilaku yang dapat menghasilkan kinerja dan prestasi. 
Kompetensi dikatakan salah satu faktor yang dapat mempengaruhi kinerja dari karyawan itu sendiri karena kompetensi merupakan karakteristik dasar dari seseorang yang memungkinkan mereka mengeluarkan kerja superior di dalam melaksanakan pekerjaannya. Sutrisno (2009) mengemukakan bahwa ada hubungan antara kompetensi yang dimiliki oleh seorang individu dan pengaruh terhadap kinerja. Maka dari itu pimpinan rumah sakit harus meningkatkan kompetensi yang dimiliki oleh setiap karyawan dengan cara melakukan pelatihan secara berkesinambungan. Kompetensi yang terdiri dari sejumlah perilaku yang dibutuhkan untuk melaksanakan peran tertentu untuk menghasilkan kinerja yang memuaskan Kompetensi memegang peranan penting dalam pencapaian tujuan organisasi. Dengan adanya kompetensi yang dimiliki oleh karyawan diharapkan dapat memberikan kontribusi yang besar terhadap kualitas pelayanan yang diberikan, dan dapat diharapkan mencapai visi, misi dan tujuan perusahaan maupun organisasi. Hal ini didukung oleh penelitian empirik yang dilakukan oleh Mikhail (2014) juga memperoleh hasil penelitian bahwa kompetensi mempunyai pengaruh signifikan dan positif terhadap kinerja. Berdasarkan hasil penelitian yang telah dikemukakan diatas maka dapat ditarik hipotesis sebagai berikut.

$\mathrm{H} 1$ : Ada pengaruh kompetensi terhadap kinerja karyawan.

Menurut Triguno (2004) menyatakan bahwa budaya kerja sudah lama dikenal manusia, namun belum disadari bahwa suatu keberhasilan kerja sangat berakar pada nilai-nilai yang dimiliki dan perilaku yang menjadi kebiasaan atau karakter. Nilai- nilai tersebut bermula dari adat istiadat, agama, norma, dan kaidah yang menjadi keyakinan pada diri pelaku pekerja maupun organsasi. Budaya kerja yang dianut oleh pimpinan perusahaan dan diimplementasikan oleh karyawan menjadi perilaku karyawan yang kemudian menentukan arah atau menunjukan keberhasilan suatu perusahaan dalam meningkatkan kinerja perusahaan. Semua bentuk aktualisasi budaya kerja bermakna komitmen.Budaya kerja disebut juga budaya organisasi, budaya organisasi sering juga disebut sebagai budaya kerja, karena tidak dapat dipisahkan dengan kinerja (performance). Budaya kerja dapat digambarkan secara khas kaitannya dengan cara orang-orang berpikir, yang mengarahkan kepada bagaimana mereka bertindak.

Sedarmayanti (2007) mengemukakan bahwa budaya kerja dapat mempengaruhi kinerja karyawan. dengan adanya budaya kerja akan mempermudah karyawan untuk menyesuaikan diri dengan lingkungan organisasi, dan membantu karyawan untuk mengetahui tindakan apa yang seharusnya dilakukan sesuai dengan nilai-nilai yang ada di dalam organisasi dan menjunjung tinggi nilai-nilai tersebut sebagai pedoman karyawan untuk berperilaku yang dapat dijalankan dalam melaksanakan tugas dan pekerjaannya. Menurut Sulaksono (2002) budaya kerja merupakan sikap dan perilaku karyawan dalam melaksanakan tugas. Sulit bagi karyawan dalam mencapai kinerja yang diharapkan tanpa adanya budaya kerja yang baik serta positif dan dengan didukung oleh sikap serta tanggung jawab yang ditunjukan oleh karyawan tersebut.

Budaya kerja sendiri merupakan suatu pola pikir yang ditemukan dan terus dikembangkan secara berkelanjutan guna menanggulangi masalah eksternal dan internal ditempat bekerja. Dengan adanya budaya kerja yang baik di tempat kerja akan sangat mempengaruhi kualitas kinerja karyawan dalam membangun kerja sama tim dan hal tersebut dapat mempengaruhi kualitas kinerja. Hal ini selaras dengan penelitian yang dilakukan oleh Kusumawati (2015) menyatakan bahwa secara parsial budaya kerja berpengaruh secara dominan terhadap kinerja karyawan. Berdasarkan hasil penelitian yang telah dikemukakan diatas maka dapat ditarik hipotesis sebagai berikut.

$\mathrm{H} 2$ : Ada pengaruh budaya kerja terhadap kinerja karyawan.

Wibowo (2007) mengatakan bahwa kompetensi dan budaya kerja dapat mempengaruhi kinerja karyawan. Kompetensi menjadi sangat berguna untuk membantu organisasi menciptakan budaya kinerja tinggi, prestasi kerja dan peningakatan kinerja karyawan. Kompetensi sangat penting karena merupakan karakteristik utama dan paling mendasar dari individu untuk menghasilkan suatu kinerja yang optimal dalam budaya kerja suatu perusahaan ataupun organisasi. Kompetensi sangat penting karena merupakan karakteristik utama dan paling mendasar dari individu untuk menghasilkan suatu kinerja yang optimal 
dalam budaya kerja suatu perusahaan ataupun organisasi. Suatu organisasi diperlukan adanya budaya kerja yang kuat agar nilai-nilai yang ada dapat benar-benar diterapkan secara mendalam, dianut dan diperjuangkan oleh para karyawan agar dapat tercipta kinerja yang baik dan juga optimal. Dengan kompetensi yang tinggi yang dimiliki karyawan dan budaya kerja yang baik pula akan sangat mendukung sebuah organisasi ataupun perusahaan dalam mencapai tujuannya dan prestasi kerja atau kinerja dari masing-masing karyawan akan meningkat pula.

Dengan karyawan memiliki kompetensi yang tinggi dan juga mampu mentaati segala budaya kerja yang ada di tempat bekerja dengan baik diharapkan dapat meningkatkan kinerja dari karyawan tersebut. Dengan adanya hal tersebut diharapkan untuk pimpinan rumah sakit dapat mengambil kebijakan agar mampu secara berkesinambungan dapat meningkatkan kompetensi karyawan dan juga meningkatkan serta mengimplementasikan budaya kerja yang baik di tempat kerja agar dapat tercipta suasana yang nyaman serta kondusif di tempat kerja sehingga hal tersebut dapat meningkatkan kinerja ataupun prestasi kerja yang dimiliki oleh masing-masing karyawan agar mampu mencapai tujuan dari perusahaan. Hal ini juga di dukung penelitian yang dilakukan oleh Syahputra (2013) bahwa kompetensi dan budaya kerja berpengaruh signifikan. Berdasarkan hasil penelitian yang telah dikemukakan diatas maka dapat ditarik hipotesis sebagai berikut H3: Ada pengaruh kompetensi dan budaya kerja terhadap kinerja karyawan.

\section{METODE}

Penelitian ini termasuk ke dalam penelitian kuantitatif kausal yang digunakan untuk memperoleh temuan eksplanasi mengenai pengaruh kompetensi (X1), Budaya Kerja (X2) dan Kinerja karyawan ( $\mathrm{Y}$ ). Variabel ini terdiri dari variabel bebas yaitu variabel yang mempengaruhi dan variabel terikat adalah variabel yang dipengaruhi atau yang menjadi akibat karena adanya variabel bebas. Dalam penelitian ini variabel bebasnya yaitu kompetensi dan budaya kerja sedangkan variabel terikatnya yaitu kinerja pada Rumah Sakit Umum Karya Dharma Husada Bros Singaraja. Subjek dalam penelitian ini adalah Divisi Umum dan SDM Rumah Sakit Umum Karya Dharma Husada Bros Singaraja dan objek penelitian ini adalah kompetensi, budaya kerja, dan kinerja karyawan. Populasi dalam penelitian ini berjumlah 50 orang.

Teknik pengambilan sampel dalam penelitian ini adalah sampel jenuh yang mana semua karyawan dijadikan sampel. Menurut Sugiyono (2001) sampling jenuh adalah teknik penentuan sampel bila semua anggota populasi dijadikan sampel. Hal ini sering dilakukan bila jumlah populasi relatif kecil kurang dari seratus. Istilah lain sampel jenuh adalah sensus, dimana semua anggota populasi dijadikan sampel.

Metode pengumpulan data dengan wawancara, observasi dan kuesioner. Kuesioner, merupakan teknik pengumpulan data primer yang dilakukan dengan cara memberikan seperangkat pertanyaan atau pernyataan tertulis kepada responden untuk dijawabnya sesuai dengan variabel yang diteliti. (Sugiyono,2010).

Analisis data yang digunakan adalah analisis regresi linear berganda dengan menggunakan Statistical Package For Social Science (SPSS) versi 24 for Windows. Sebelum data diolah ke analisis regresi berganda, terlebih dahulu diuji dengan pengujian asumsi klasik, karena syarat untuk memperoleh analisis regresi yang baik. Adapun uji asumsi klasik tersebut yang meliputi : (1) Uji Normalitas, (2) Uji Multikolinearitas, (3) Uji Heteroskdasitas. Diharapkan mendapatkan hasil model regresi yang sesuai kaidah BLUE ( Best Linier Unbiased Estimator).

\section{HASIL DAN PEMBAHASAN}

Hasil

Hasil analisis uji regresi linier berganda pengaruh kompetensi dan budaya kerja terhadap kinerja karyawan Divisi Umum dan SDM Rumah Sakit Umum Karya Dharma Husada Bros Singaraja yang dapat dilihat dari Tabel 1. 
Hasil Analisis Regresi Linier Berganda

Pengaruh Kompetensi $\left(\mathrm{X}_{1}\right)$ dan Budaya Kerja $\left(\mathrm{X}_{2}\right)$ Terhadap Kinerja Karyawan $(\mathrm{Y})$

\begin{tabular}{llll}
\hline \multicolumn{1}{c}{ Parameter } & \multicolumn{1}{c}{ Nilai } & \multicolumn{1}{c}{ P-Value } & \multicolumn{1}{c}{$\begin{array}{c}\text { Alpha } \\
(\mathbf{\alpha})\end{array}$} \\
\hline $\mathrm{Ryx}_{1} \mathrm{x}_{2}$ & 0,912 & 0,000 & 0,05 \\
\hline $\mathrm{R}^{2} \mathrm{yx}_{1} \mathrm{x}_{2}$ & 0,824 & - & - \\
\hline$\varepsilon$ & 0,169 & - & - \\
\hline $\mathrm{Pyx}_{1}$ & 0,845 & 0,000 & 0,05 \\
\hline $\mathrm{P}^{2} \mathrm{yx}_{1}$ & 0,714 & - & - \\
\hline $\mathrm{Pyx}_{2}$ & 0,817 & 0,000 & 0,05 \\
\hline $\mathrm{P}^{2} \mathrm{yx}_{2}$ & 0,667 & - & - \\
\hline $\mathrm{A}$ & 9,775 & 0,000 & 0,05 \\
\hline $\mathrm{b}_{1}$ & 0,515 & 0,000 & 0,05 \\
\hline $\mathrm{b}_{2}$ & 0,330 & 0,000 & 0,05 \\
\hline
\end{tabular}

Sumber: Output SPSS 24.0 for Windows

Berdasarkan hasil uji regresi linier berganda yang telah dilakukan, maka diperoleh hasil yang dapat dilihat pada tabel 1, maka dengan ini diperoleh struktur pengaruh variabel kompetensi dan budaya kerja terhadap kinerja karyawan yang tampak pada Gambar 1.

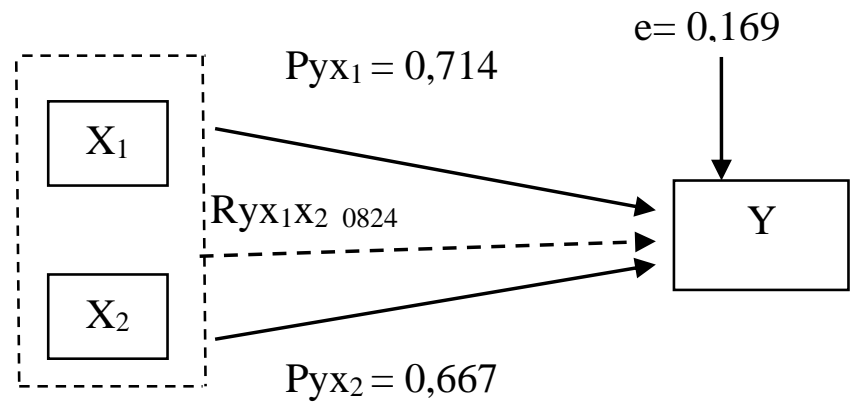

Gambar 1. Struktur pengaruh variabel kompetensi $\left(X_{1}\right)$ dan budaya kerja $\left(X_{2}\right)$ terhadap kinerja karyawan $(\mathrm{Y})$.

\section{Pembahasan}

Berdasarkan Tabel 1. Dapat di interpretasikan hubungan antar variabel yakni sebagaii berikut: (1) $\operatorname{Ryx}_{1} x_{2}$ menunjukan ada hubungan simultan dari kompetensi dan budaya kerja terhadap kinerja karyawan sebesar 0,912 atau 9,12\%, R2 $\mathrm{yx}_{1} \mathrm{x}_{2}$ menunjukan besar sumbangan pengaruh simultan kompetensi dan budaya kerja terhadap kinerja karyawan adalah 8,24\%. (2) Secara parsial menunjukan kompetensi terhadap kinerja karyawan sebesar dengan sumbangan pengaruh parsial 0,714 atau $71,4 \%$. (3) Sedangkan Secara parsial menunjukan budaya kerja terhadap kinerja karyawan sebesar 0,817 atau 81,7\% dengan sumbangan pengaruh parsial 0,667 atau 66,7\%.(4) Parameter $\varepsilon$ menunjukan sumbangan pengaruh faktor lain terhadap kinerja karyawan sebesar 0,169 atau 16,9\%.

Hipotesis penelitian yang pertama "ada pengaruh secara parsial dari kompetensi terhadap kinerja karyawan". Berdasarkan hasil nilai t hitung sebesar 10,842 untuk variabel kompetensi sedangkan nilai t tabel sebesar 2,012. Maka diketahui $t$ hitung $>t$ tabel, dengan nilai sig $0,000<0,05$. Sehingga $\mathrm{HO}$ ditolak dan Ha diterima, ini artinya bahwa kompetensi secara parsial berpengaruh positif dan signifikan terhadap kinerja karyawan pada Rumah Sakit Umum Karya Dharma Husada Bros Singaraja. Maka dapat disimpulkan ada pengaruh secara parsial dari variable kompetensi terhadap kinerja karyawan sebesar 0,845 atau $84,5 \%$. 
Hipotesis penelitian kedua "ada pengaruh secara parsial dari budaya kerja terhadap kinerja karyawan'. Berdasarkan hasil nilai t hitung sebesar 9,709 untuk variabel budaya kerja sedangkan nilai t tabel sebesar 2,012. Maka dapat diketahui t hitung $>t$ tabel, dengan nilai sig $0,000 \leq 0,05$. Sehingga HO diterima dan Ha ditolak, ini artinya bahwa budaya kerja berpengaruh positif dan signifikan terhadap kinerja karyawan pada Rumah Sakit Umum Karya Dharma Husada Bros Singaraja. Dapat disipulkan bahwa ada pengaruh parsial budaya kerja terhadap kinerja karyawan sebesar 0,667 atau

Hasil hipotesis penelitian yang ketiga "ada pengaruh kompetensi dan budaya kerja terhadap kinerja karyawan". Berdasarkan hasil nilai F hitung yang diperoleh sebesar 115,469 sedangkan nilai $F$ tabel sebesar 3,195. Maka dapat diketahui nilai $F$ hitung 115,469 $>\mathrm{F}$ tabel 3,195 dengan tingkat signifikan sebesar $0,000<0,05$, maka dapat disimpulkan bahwa ada pengaruh simultan dari komptensi dan budaya kerja terhadap kinerja karyawan pada Rumah Sakit Umum Karya Dharma Husada Bros Singaraja sebesar 0,912 dengan sumbangan pengaruh sebesar $8,24 \%$

Hasil penelitian ini telah menunjukkan bahwa kompetensi dan budaya kerja mempengaruhi kinerja karyawan pada Rumah Sakit Umum Karya Dharma Husada Bros Singaraja Divisi Umum dan SDM. Oleh karena itu, hasil penelitian ini memberikan implikasi bahwa untuk meningkatkan kinerja karyawan pihak pimpinan Rumah Sakit Karya Dharma Husada Bros Singaraja perlu memperhatikan kompetensi dan budaya kerja yang dimiliki oleh setiap karyawan. Jika kompetensi dan budaya kerja karyawan yang rendah maka akan berakibat pada rendahnya kinerja karyawan pada Rumah Sakit Umum Karya Dharma Husada Bros Singaraja. Apabila pihak rumah sakit tidak meningkatkan kompetensi dan budaya kerja dari para karyawan maka kinerja karyawan akan terus menurun dan akan berdampak buruk pada kinerja karyawan Rumah Sakit Umum Karya Dharma Husada Bros Singaraja. Jika kinerja karyawan menurun, maka akan mengakibatkan rendahnya pelayanan yang didapatkan oleh masyarakat.

Dengan demikian, Rumah Sakit Umum Karya Dharma Husada Bros Singaraja harus mampu meningkatkan kompetensi maupun budaya kerja yang sudah berlaku pada rumah sakit tersebut dengan cara (1) Meningkatkan standar kompetensi yang dimiliki oleh karyawan seperti meningkatkan pendidikan sesuai dengan aturan yang berlaku pada rumah sakit (3) Mengadakan pelatihan kepada karyawan agar mampu meningkatkan kompetensi dalam bekerja (4) Mengimplementasikan pelatihan yang di dapat tersebut secara rutin (5) Adakan peraturan review performa pada masing-masing karyawan. Kemudian cara yang dilakukan untuk meningkatkan budaya kerja para karyawan yaitu (1) Mengadakan family gathering agar mampu mempererat kerjasama antar tim dan mampu memperbaiki komunikasi antar karyawan, sehingga diharapkan di lingkungan kerja dapat menciptakan suasana yang kondusif serta dapat meningkatkan kinerja dari masing-masing karyawan. (2) Memberikan reward kepada karyawan yang berprestasi dan punishment yang sesuai untuk karyawan yang melanggar aturan (3) Mampu menyiapkan diri ketika terjadi pengecekan mendadak dan mempelajari hal yang berkaitan dengan rumah sakit. Dengan meningkatkan kompetensi dan budaya kerja yang ada pada rumah sakit tersebut, diharapkan dapat membantu meningkatkan kinerja karyawan pada Rumah Sakit Umum Karya Dharma Husada Bros Singaraja yang akan berdampak pada hasil kerja atau prestasi kerja karyawan di rumah sakit tersebut.

\section{Simpulan dan Saran \\ Simpulan}

Berdasarkan hasil pengujian statistik dan hipotesis serta pembahasan yang telah dilakukan sebelumnya, maka dapat ditarik beberapa kesimpulan sebagai berikut: (1) kompetensi berpengaruh positif dan signifikan terhadap kinerja karyawan Rumah Sakit Umum Karya Dharma Husada Bros Singaraja. Maka dari itu sangat diperlukan adanya peningkatan kompetensi seluruh karyawan yang ada pada rumah sakit tersebut dengan cara melanjutkan pendidikan yang sesuai dengan aturan rumah sakit yang terbaru dan mengadakan pelatihan dan review dari adanya pelatihan pelatihan tersebut. (2) Budaya kerja karyawan berpengaruh positif dan signifikan terhadap kinerja karyawan Rumah Sakit Umum 
Karya Dharma Husada Bros Singaraja. Budaya kerja yang baik dapat membuat suasana kerja menjadi baik pula dan penilaian terhadap suasana kerja pada rumah sakit menjadi baik pula. (3) Kompetensi dan budaya kerja berpengaruh positif dan signifikan terhadap kinerja karyawan Rumah Sakit Umum Karya Dharma Husada Bros Singaraja.

\section{Saran}

Berdasarkan hasil pembahasan dan simpulan yang telah dikemukakkan di atas maka dapat diajukan beberapa saran yaitu (1) Bagi pimpinan pada Rumah Sakit Umum Karya Dharma Husada Bros Singaraja khususnya pada Divisi Umum dan SDM untuk dapat lebih memperhatikan pendidikan yang ditempuh dari para karyawan agar karyawan dapat memenuhi standar pendidikan yang sesuai dengan standar pendidikan yang telah ditetapkan rumah sakit. Dalam hal kinerja karyawan dalam bekerja agar pekerjaan dapat selesai pada batas waktu yang telah ditentukan. Meningkatkan standar kompetensi yang dimiliki oleh karyawan seperti meningkatkan pendidikan sesuai dengan aturan yang berlaku pada rumah sakit, Mengadakan pelatihan kepada karyawan agar mampu meningkatkan kompetensi dalam bekerja, Mengimplementasikan pelatihan yang di dapat tersebut secara rutin serta berkesinambungan.

Budaya kerja yang ada pada Rumah Sakit Karya Dharma Husada Bros Singaraja tersebut. Caranya yaitu dengan memberikan teguran maupun sanksi yang tegas kepada para karyawan yang tidak mematuhi peraturan maupun tidak ada rasa sikap toleransi kepada teman. Sanksi yang diberikan berupa penundaan kenaikan gaji, dan penundaan kenaikan jabatan dan sanksi tertulis lainnya. Diberikannya sanksi seperti itu karyawan akan memiliki rasa takut dan karyawan akan bekerja dengan lebih optimal dan mematuhi aturan yang ada di rumah sakit tersebut. Jika hal tersebut bisa berjalan dengan baik, maka kinerja karyawan dalam bekerja dapat berjalan dengan optimal dan meningkatnya kinerja karyawan. (2) Agar budaya kerja dapat dipatuhi oleh seluruh karyawan, semestinya dibuatkan aturan yang tertulis beserta saknsi yang tegas bagi karyawan yang melanggarnya. Karena budaya kerja sendiri merupakan cerminan perilaku karyawan dalam melaksanakan pekerjaan dan membentuk etos kerja yang baik serta kedisiplinan bagi karyawan tersebut.

Bagi peneliti salanjutnya yang tertarik untuk mengkaji aspek yang serupa yaitu kompetensi dan budaya kerja terhadap kinerja karyawan diharapkan untuk mengembangkan penelitian inii dengan menggunakan populasi dan sampel yang lebih luas agar lebih teruji kehandalannya. Disamping itu diharapkan untuk menguji variabel lain yang diduga kuat dapat mempengaruhi kinerja karyawan. Selain itu diharapkan untuk mengembangkan penelitian ini dengan menggunakan subjek penelitian yang lebih luas. Keterbatasan dari penelitian ini adalah tidak adanya data pembanding di perusahaan yang sejenis sehingga peneliti susah untuk membandingkan kinerja karyawannya, dan dalam proses pengambilan data, informasi yang diberikan responden melalui kuesioner terkadang tidak menunjukan pendapat responden yang sebenarnya, hal ini terjadi karena perbedaan pemikiran, dan pemahaman yang berbeda dari tiap responden. Bagi peneliti lain yang ingin meneliti hal sejenis, pada saat pengisian kuesioner, diperlukan adanya pendampingan terhadap responden agar responden lebih memahami dan memberikan jawaban yang sesuai dengan kehendak responden.

\section{DAFTAR PUSTAKA}

Dessler. 2006. Manajemen Sumber Daya Manusia Jilid 1. Jakarta: PT Indeks

Hasibuan, Malayu S.P. 2006. Manajemen Sumber Daya Manusia Dalam Manajemen Sumber Daya Manusia. Jakarta: PT. Bumi Aksara

--------.2006. Manajemen Sumber Daya Manusia Edisi Revisi Cetakan Kedelapan. Jakarta: PT Bumi Aksara.

Iswahyu. (2014). Pengaruh Kesesuaian Kompetensi dan Motivasi Kerja Terhadap Kinerja Pegawai Pada Sekretariat Daerah Kabupaten Malang. Jurnal Eksekutif, Volume 2, Nomor I, April 2005, Hal 63-80 
Kusumawati. 2015. “Analisis Pengaruh Budaya Kerja Dan Semangat Kerja Terhadap Kinerja Karyawan Bank Mandiri KCP Puger Jember"

Mangkunegara. 2005. Perilaku dan Budaya Organisasi Cetakan Pertama. Malang: Remaja Rosda Karya.

Mikhail,dkk. (2014). Pengaruh Kompetensi dan Kepuasan Kerja Terhadap Kinerja Karyawan Rumah SAKIT Pekanbaru.. Jom FEKON 1 No 2.

Sedarmayanti. 2007. Sumber Daya Manusia dan Produktivitas Kerja. Bandung: Penerbit Mandar Maju

Sugiyono. (2001). Metode Penelitian Administrasi, Penerbit Alfabeta Bandung.

----- 2010. Statistika Untuk Penelitian. Bandung: Alfabeta.

Sulaksono. 2002. Pengantar Organisasi dan Manajemen. Yogyakarta: Fisipol Universitas Negeri Surakarta.

Sutrisno. E (2009). Manajemen Sumber Daya Manusia. Jakarta: Kencana Prenada Media Group

Syahputra.2013.Pengaruh Kompetensi Budaya Kerja dan kepuasan kerja Terhadap Kinerja Pegawai pada Kantor Camat Meral Kabupaten Karimun.

Triguno. (2004). Budaya Kerja. Menciptakan Lingkungan Yang Kondusif Untuk Meningkatkan Produktivitas Kerja, Edisi 6, PT Golden Trayon Pres, Jakarta.

Wibowo.2007 Budaya Organisasi Sebuah Kebutuhan Untuk Meningkatkan Kinerja Jangka Panjang. Jakarta:PT Raja Grafindo Persada.

--------. 2007. Budaya Organisasi Sebuah Kebutuhan Untuk Meningkatkan Kinerja Jangka Panjang. Jakarta:PT RajaGrafindo Persada.

Wibowo. 2013. Manajemen Kinerja. Jakarta: PT. Raja Grafindo Persada

World Health Organization. Definisi rumah sakit : WHO. 2008. Available from :www.who.int. (6 Desember 2019) 